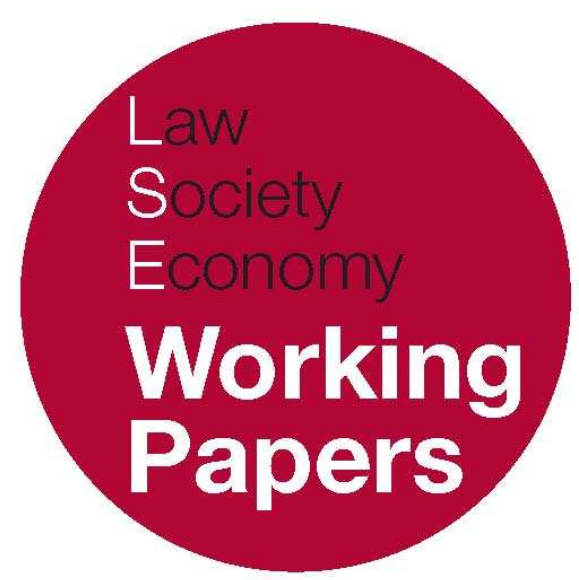

\title{
Confronting Confrontation
}

\author{
Mike Redmayne \\ LSE Law, Society and Economy Working Papers 10/2010 \\ London School of Economics and Political Science \\ Law Department
}

This paper can be downloaded without charge from LSE Law, Society and Economy Working Papers at: www.lse.ac.uk/collections/law/wps/wps.htm and the Social Sciences Research Network electronic library at: http://ssrn.com/abstract $=1616200$.

(C) Mike Redmayne. Users may download and/or print one copy to facilitate their private study or for non-commercial research. Users may not engage in further distribution of this material or use it for any profit-making activities or any other form of commercial gain. 


\title{
Confronting Confrontation
}

\author{
Mike Redmayne*
}

\begin{abstract}
The right to confront adverse witnesses has brought the English courts into conflict with the European Court of Human Rights. Drawing on confrontation doctrine in Europe and the United States, this paper argues that there is no convincing rationale for the sort of strong confrontation right found under the ECHR and the US constitution. A more pragmatic approach to confrontation, based on the best evidence principle, is advocated.
\end{abstract}

\section{INTRODUCTION}

The right to confrontation has brought English courts into a showdown with the European Court of Human Rights. Article 6(3) of the ECHR provides that 'everyone charged with a criminal offence' has the right to 'examine or have examined witnesses against him'. This basically means that the accused, or his lawyer, should have a chance to put questions to adverse witnesses. In the combined cases of Al-Khawaja and Tahery v United Kingdom, ${ }^{1}$ the prosecution had introduced witness statements from witnesses who were not present at the defendants' trials. Strasbourg held that there was a breach of the confrontation right because the convictions were based 'solely or to a decisive extent' on the evidence of absent witnesses, even where the witness was absent for good reason:

\footnotetext{
* Law Department, London School of Economics and Political Science. A version of this paper was presented at a conference on Evidence Law and Human Rights at the University of New South Wales in April 2010. I am grateful to the participants for their comments, and to Sydney Law School for hosting me when I got stranded.

1 (2009) 49 EHRR 1.
} 
in Al-Khawaja the witness (the complainant in a sexual assault trial) was dead. The English courts have found this hard to accept. In Horncastle the UK Supreme Court and Court of Appeal agreed that the ECtHR jurisprudence on confrontation should not be followed. ${ }^{2}$ English hearsay law is therefore currently in conflict with the Convention: defendants can be convicted on hearsay evidence, in breach of Article 6. Al-Khawaja has now had a rehearing before the ECtHR's Grand Chamber, so a second judgment is awaited. ${ }^{3}$ While it is possible that the Court will relent, it is just as likely that it will stick to its hard line - an approach that many commentators think is right. ${ }^{4}$

Confrontation rights also have a lively recent history in the United States. The Sixth Amendment to the US Constitution provides that in all criminal prosecutions, the accused shall enjoy the right $[\ldots]$ to be confronted with the witnesses against him'. In a 2004 decision, Cranford v Washington, ${ }^{5}$ the Supreme Court reinvigorated this clause, finding, in a reversal of its previous approach, that even if there are indications that a witness statement is reliable, it would not necessarily be admissible under the Confrontation Clause. ${ }^{6}$ The evidence at issue in Al-Khawaja and Tabery would now not be admissible in the United States. To this extent the American echoes the European approach. However, confrontation law in the two jurisdictions also differs. Simply put, the US approach is rather stricter than the European one - there is no exception, for example, for evidence which is not the 'sole or decisive' basis on which the accused is convicted. In a series of cases since Cranford, the Supreme Court has reiterated its strict approach, while filling out the details of the confrontation right - though not without dissent.

It is obvious that there is much at stake in debates about confrontation. Where a witness makes a statement to the police incriminating the accused and then dies, or cannot be found, or is no longer fit to testify, or, perhaps, is too scared to come to court, then her statement cannot be introduced at trial. While under the European approach there is the caveat that the evidence can be admitted if it is not 'sole or decisive', the practical effect in both jurisdictions is the same: where a prosecution depends on the evidence of an absent witness, the prosecution must fail, even if a court provided with the evidence would consider the case to be proved beyond reasonable doubt. In this paper I take a close look at confrontation, in particular exploring its theoretical basis, in order to see whether this result can be justified. I may as well say at the outset that I do not believe that

\footnotetext{
2 R v Horncastle and Others [2009] 2 Cr App R 15 (CA); [2009] UKSC 14.

3 The case was heard on 19 May 2010. A webcast of the hearing is available at http://www.echr.coe.int/ECHR/EN/Header/Press/Multimedia/Webcasts+of+public+hearings/webca stEN_media?\&p_url=20100519-1/lang/.

${ }^{4}$ See, eg, S. Trechsel, Human Rights in Criminal Proceedings (Oxford: OUP, 2005) ch 11. See further the views of commentators such as Friedman and O'Brian, discussed below. But cf I. Dennis, 'The Right to Confront Witnesses: Meanings, Myths and Human Rights' (2010) Crim LR 255.

5541 US 36 (2004).

${ }^{6}$ The previous authority was Obio v Roberts 448 US 56 (1980), under which the confrontation right would be satisfied if the evidence at issue bore 'indicia of reliability', which might be either case specific or presumed because the evidence was admissible under a 'firmly rooted' hearsay exception.
} 
it can be - though that is not to say that there is no value in confrontation, nor that the failure to afford it to the accused should never be a bar to conviction. I confine the discussion to absent witnesses, although in Europe the confrontation right has also generated a significant case law on anonymous witnesses. ${ }^{7}$ While my principle focus is on the situation in Europe, I pay considerable attention to US case law and scholarship, for it is here that we find the richest attempts to define and justify a confrontation right.

Analysis of confrontation is not straightforward, because neither the ECtHR nor the US Supreme Court has elaborated a detailed theory of confrontation. Indeed, the Supreme Court has been criticised for developing a case law under which the most that can be said is that 'the purpose of confrontation is confrontation'. ${ }^{8}$ In that respect, there is no clear target to aim at. The scholarly literature is somewhat more helpful, but scholars have offered a range of ways of theorising confrontation, and these theories tend to have different implications for the scope of the confrontation right. As I hope to show, to that extent, theory matters. The analysis will start, however, not with the theory but with a closer look at confrontation doctrine in the two jurisdictions. This will give us a clearer idea of what we are dealing with, and just what it is that any theory of confrontation needs to justify.

\section{CONFRONTATION IN EUROPE AND THE UNITED STATES}

\section{SCOPE}

The confrontation right overlaps with, but is narrower than, the hearsay rule. The hearsay rule has, at least prima facie, a wide scope. A simple explanation of the rule is that 'a statement other than one made by a person while giving oral evidence in the proceedings is inadmissible as evidence of any fact stated'. ${ }^{9}$ While the rule has been tweaked slightly by the Criminal Justice Act 2003, in an attempt to make it clear that 'implied assertions' are not facts stated and therefore not excluded by the hearsay rule, ${ }^{10}$ the rule still applies to a wide range of statements. Statements made to the police are covered, but so are statements made in informal conversations between friends and statements made in business records, such as a factory record of the engine block numbers of cars. ${ }^{11}$ In the United States at least, it is clear that the scope of the confrontation right does not extend this far. Under

\footnotetext{
${ }^{7}$ See, eg, Doorson v The Netherlands (1996) 22 EHRR 330. For the UK reaction, and detailed discussion of the ECHR cases, see R v Davis [2008] UKHL 36.

${ }^{8}$ See R. Park, 'Is Confrontation the Bottom Line?' (2006-7) 19 Regent U L Rev 459, 467. Park attributes the phrase to Peter Tillers.

9 R. Cross, Cross on Evidence (London: Butterworths, 5th ed, 1979) 6.

${ }^{10}$ ss 114,115 . Whether this successfully excludes implied assertions is a complex issue: D. Birch and M.

Hirst, 'Interpreting the New Concept of Hearsay' (2010) 69 CLJ 72.

11 The facts of Myers v DPP [1965] AC 1001.
} 
Crawford, it has been held to apply only to 'testimonial' statements. 'Testimonial' is intended to pick out reasonably formal statements, ${ }^{12}$ but the Supreme Court has declined to give a precise definition of the concept. In Cranford itself it observed that various definitions had been offered in argument; perhaps the widest of these was 'statements that were made under circumstances which would lead an objective witness to believe that the statement would be available for use at a later trial'.13 In later cases the Court has still declined to define 'testimonial', but it has held that laboratory reports by forensic scientists are testimonial, ${ }^{14}$ as are statements made by a complainant to the police shortly after an alleged incident of domestic violence. ${ }^{15}$ Statements made in an emergency telephone call to the police, however, were not classified as testimonial, because the operator would have been concentrating on dealing with the emergency rather than producing evidence for later trial. ${ }^{16}$

Under the ECHR, things are less clear, but it may well be that the right in Article 6(3) does not apply to more informal types of hearsay. In all of the cases where a violation has been found, the problematic evidence seems to have been statements made to investigative authorities - police officers or examining judges $;{ }^{17}$ indeed, the Court commonly uses the word 'deposition' to describe the type of evidence to which the confrontation right attaches. ${ }^{18}$ Thus where a witness gives what a common lawyer regards as hearsay evidence, there may not be an issue under the Convention so long as the hearsay evidence does not take the form of a witness statement. In $A M \mathrm{v}$ Italy, $\mathrm{G}$, a child, had complained to his parents that during a holiday in Italy he had been indecently assaulted by the applicant. ${ }^{19}$ Statements were taken from G's parents and from a psychotherapist who was treating him. The arguments before the ECtHR focussed on the absence of confrontation of these witnesses, with the Court finding a breach of 6(3) because the applicant 'did not have a chance to examine the witness statements that formed the basis of his conviction.'20 This suggests that had these witnesses

\footnotetext{
${ }^{12}$ See Crawford, n 5 above, 51: 'An accuser who makes a formal statement to government officers bears testimony in a sense that a person who makes a casual remark to an acquaintance does not.' See also Giles v California 554 US _ (2008) at 22: 'statements by friends and neighbours [...] and statements to physicians $[\ldots]$ ' would not be excluded under the confrontation clause.

13 n 5 above, 52.

${ }^{14}$ Melendez. Dią v Massachusetts 557 US _ (2009).

15 Davis v Washington 547 US 813 (2006).

$16 \mathrm{ibid}, 822$

${ }^{17}$ See J.R. Spencer, Hearsay Evidence in Criminal Proceedings (Oxford: Hart Publishing, 2008) 43-44.

${ }^{18} \mathrm{eg}$ AM v Italy Appln No 37019/97 (1999) at [25]; Luca v Italy (2003) 36 EHRR 46 at [40]; PS v Germany (2003) 36 EHRR 61 at [24]. Another common formulation is 'statements made at the investigative stage', eg Gossa v Poland Appln No 47986/99 (2007). On the other hand, the text of article 6(3) refers to 'witnesses' which, in some cases, has been given a reasonably wide interpretation, to include anyone whose statements are relied on by the court, eg Kostovski v Netherlands (1990) 12 EHRR 434 at [40]; though note the reference to 'statements, as recorded by the police' in $S N$ v Sweden (2004) EHRR 13 at [45].

19 ibid.

20 ibid at [28].
} 
been confronted, proceedings would have been Convention compliant, even though the witnesses would have been relating hearsay, ie what $\mathrm{G}$ had told them. ${ }^{21}$

Some witnesses may make statements to the police that, while helpful to the prosecution case, do not directly incriminate the accused: an example would be a statement such as 'I heard a gunshot at 11 o'clock'. In contrast, all of the cases in which the ECtHR has found a violation seem to have involved accusatory statements, where the defendant accuses a specific person of a crime. ${ }^{22}$ In $X \mathrm{v}$ United Kingdom, various people who had filmed an incident in Northern Ireland at which the killing of two soldiers took place were allowed to give evidence in court anonymously. ${ }^{23}$ The evidence apparently involved the witnesses describing the making of their films and photos of the incident; they did not identify the applicant themselves. There were several reasons why the Commission found that in this case anonymity did not infringe the confrontation right, but one was that this evidence 'did not implicate the applicant'. ${ }^{24}$ There is very little to go on here, so it is impossible to say how significant this observation is, or how accusatory a statement would have to be before it required confrontation: an eyewitness who provides a description to the police of the person who attacked her might be said to implicate a defendant without accusing him. ${ }^{25}$ But while one can only speculate as to what the scope of the ECHR's confrontation right is, there must surely be some limit to the right. Otherwise the prosecution would not be able to rely on business records in a case where the original maker of the record was dead or could no longer be identified.

There are various reasons why the restricted focus of the confrontation right is significant. One is that it undermines some of the arguments made in Horncastle, the case where the UK Supreme Court and Court of Appeal refused to follow the ECtHR's decision in Al-Khawaja. ${ }^{26}$ The main argument in the judgments is that hearsay can sometimes be perfectly reliable, and thus to rule that it cannot be the 'sole or decisive' element in a conviction is to take an unnecessarily strict approach. But, if it is right that Strasbourg sees confrontation as confined to statements made to the authorities, the English courts, by framing the argument in

\footnotetext{
21 cf S.J. Summers, 'The Right to Confrontation After Crawford v. Washington: A "Continental European" Perspective' (2004) 2 International Commentary on Evidence 8, who claims that the ECHR would apply in this situation, though she cites no evidence in support. See also S. Maffei, The European Right to Confrontation in Criminal Proceedings: Absent, Anonymous and Vulnerable Witnesses (Groningen: Europa, 2006) 74 ('occasionally, statements to private third parties (such as doctors, friends, or relatives) have also been dealt with under Article 6, when they have been relied upon as hearsay': again, no authorities are cited in support)).

${ }^{22}$ See W.E. O’Brian, 'The Right of Confrontation: US and European Perspectives' (2005) 121 LQR 481, 494.

23 (1993) 15 EHRR (CD) 113.

24 ibid at [1].

25 This way of thinking about confrontation was explicitly rejected by a majority of the US Supreme Court in Melendez Diaz, n 14 above, 7-9.

${ }^{26}$ n 2 above.
} 
terms of hearsay, are to some extent missing the point. ${ }^{27}$ This is most obvious when we consider a series of examples given by the Court of Appeal, and endorsed by the Supreme Court, which are intended to demonstrate that Strasbourg is being too strict. ${ }^{28}$ In one example a woman makes an emergency telephone call to the police and identifies the person who is attacking her. But this is not really a statement made in response to police questioning, and so might not be seen as a 'statement' or 'deposition' in the ECtHR's terms. Nor, in all likelihood, would it be regarded as testimonial in the US. ${ }^{29}$ Another example involves bank records in a fraud case; here it is even clearer that the records would not be regarded as prompting confrontation in either jurisdiction. ${ }^{30}$ The example that comes closest to raising a confrontation issue 31 involves a witness who writes down the registration number of a car involved in a drive-by shooting; there is sufficient corroborating evidence to rule out the possibility of mistake. If the witness reports the number to the police, then there is a good chance that the confrontation right under the ECHR and the Sixth Amendment would apply. But Strasbourg's answer cannot quite be predicted with confidence, for in the terms introduced above the report of the number plate implicates but does not accuse. A better example would be one where the witness claims to recognise the car's driver, and gives the police a specific person's name. This is plainly accusatorial and does not, I think, quite deliver the intuition that the Court of Appeal wanted: that there would be no value in confrontation.

\section{WHAT DOES CONFRONTATION INVOLVE?}

Paradigmatically, confrontation involves the relevant witness testifying in the accused's physical presence at trial, with the accused being able to put questions. ${ }^{32}$ But departures from this paradigm may be permissible. In its pre-Cranford case law, the United States Supreme Court ruled that procedures allowing child

27 The conflation of hearsay and confrontation is especially puzzling because the distinction was discussed by the Court of Appeal in Owen [2001] EWCA Crim 1018. The point is also clearly made by Spencer, $\mathrm{n} 17$ above, $43-44$.

$28 \mathrm{n} 2$ above at [61]-[63].

${ }^{29}$ See Davis, n 15 above. Confrontation would not be required so long as the emergency operator could objectively be considered as concentrating on responding to the emergency.

${ }^{30}$ But note Papageorgiou v Greece Appln No 59506/00 (2003), where the rest of the right specified in Art $6(3)(\mathrm{d})$ ('[...] to obtain the attendance and examination of witnesses on his behalf [...]') was used to criticise a failure to provide the originals of various documents.

31 I ignore an example in which a defendant signals willingness to plead guilty to a charge of drug possession, as the example is too under-described to make sense of.

32 Some would contend that true confrontation should involve the defendant having a right to crossexamine the witness in person: for example, Friedman has argued that provisions in the Youth Justice and Criminal Evidence Act 1999, denying this right in certain circumstances, are objectionable. See R.D. Friedman, 'Thoughts From Across the Water on Hearsay and Confrontation' (1998) Crim LR 697, 708709. It is clear that under the ECHR there is no right to cross-examine in person, eg $S N \mathrm{v}$ Sweden (2004) EHRR 13. 
witnesses to testify by video link could be constitutional. ${ }^{33}$ It is not clear whether the Court would come to the same decision post-Crawford. ${ }^{34}$ Under Crawford, however, it is clear that if the witness will be unavailable at trial, the confrontation right can be satisfied by giving the defendant the opportunity to put questions to the witness prior to the trial - in other words, without the fact-finder being present. ${ }^{35}$ It is hard to imagine that anonymous witness testimony would be permissible in the United States.

The European Court of Human Rights' approach to confrontation puts less emphasis on the witness testifying in the physical presence of the accused. The core of the right under the ECHR seems to be that the accused should have some ability to put questions to the witness: procedures whereby the witness is questioned pre-trial, outside the presence of the accused or his lawyer, but where the defence has the ability to influence the questions put to the witness, may comply with Article 6(3). ${ }^{36}$ Witness anonymity is permitted, so long as 'counterbalancing' measures are in place. ${ }^{37}$ Testimony via video link would not raise an issue under the Convention. ${ }^{38}$

\section{EXCEPTIONS}

For the purposes of this paper, the most significant exception to the confrontation right is forfeiture, considered separately below. Other than forfeiture, the confrontation right in the United States may be exceptionless - though in Cranford the Supreme Court noted that dying declarations might be seen as an exception, because they were so considered at the time the Constitution was written..$^{39}$ Dying declarations, however, are a narrow category. ${ }^{40}$ The evidence at issue in Al-Khawaja was not a dying declaration, because the witness was not dying when it was made. The fact that she later died, and so could not testify at trial, would not give rise to an exception in the United States. As we have seen, the position under the ECHR is similar: where confrontation is concerned, impossibility is no excuse. However,

\footnotetext{
33 Maryland v Craig 497 US 836 (1990), a 5-4 majority decision. In an earlier case, Coy v Iowa 487 US 1012 (1988), special measures (the use of a screen to obstruct the complainant's view of D) were held to breach the Confrontation Clause, because there was no showing of necessity. Thus interferences with the 'face to face' aspect of confrontation need to be carefully justified.

34 The Court has denied certiorari in one case that would have raised the issue. See 'A Challenge to Maryland v Craig', at http://confrontationright.blogspot.com, entry for March 21 2007. The case was Vogelsberg v Wisconsin, petition 06-1253, and certiorari is recorded as denied in the Supreme Court's Order List for May 142007.

${ }^{35}$ Crawford, $n 5$ above, 68.

36 SN v Sweden (2004) EHRR 13. It is important that D is legally advised at any pre-trial confrontation: Melnikov v Russia Appln No 23610/03 (2010).

37 Doorson v Netherlands (1996) 22 EHRR 330.

38 In Accardi v Italy Appln No 30598/02 (admissibility decision, 2005), a procedure whereby the complainants were questioned prior to trial, outside D's presence (but where D had an opportunity to put questions), and a video tape of the questioning was presented at trial, was found not to infringe Art 6. ${ }^{39}$ Crawford, $\mathrm{n} 5$ above, $56 \mathrm{n} 6$.

${ }^{40}$ Not just any statement by a dying person is admissible. Under the US Federal Rules of Evidence (rule 804(a)), the statement is only admissible in a prosecution for murder, if it relates to the cause of death, and was made in the belief that death was imminent.
} 
Strasbourg does take a more flexible approach than the US Supreme Court, in that a statement made by an absent witness will be admissible if it is not the 'sole or decisive' basis of conviction. This is a vague criterion - almost any evidence relied on by the prosecution might turn out to be decisive, in that it might be the feather that tips the scales - and it has not always been consistently applied by the ECtHR. ${ }^{41}$ In recent cases, however, the notion seems to be applied quite strictly. In Al-Khawaja the witness statement was reasonably well corroborated: another complainant had made a similar allegation against the defendant, and the absent witness had initially made her allegations to friends. But the statement was still considered to be decisive. There is some ambiguity in the judgment, however, as to whether use of a decisive statement from an absent witness will inevitably make the trial unfair. The Government argued that, because Al-Khawaja had had alternative means of challenging the witness statement, there were measures in place to 'counter-balance' the lack of confrontation. The ECtHR disagreed on the facts, but did not quite rule out the possibility of counter-balancing. ${ }^{42}$

\section{FORFEITURE}

In the United States under Cranford, the only significant exception to the confrontation right is forfeiture. The defendant can lose the confrontation right through his own wrongful behaviour. This exception was noted in Crawford, and considered in detail in Giles v California.43 In Giles, D had killed his former girlfriend. He claimed self-defence, and the prosecution introduced evidence of the girlfriend's statements made to a police officer responding to an earlier incident of domestic violence. While recognising a forfeiture exception, a majority of the Supreme Court held that the mere fact that the victim had died at Giles's hands was not enough to engage forfeiture. The exception was construed narrowly, as applying only to conduct designed to prevent the victim from testifying. While, in a rather strained argument, the majority did suggest that a court might find that Giles had forfeited his right on the grounds that one of the purposes of domestic violence is to control and isolate the victim, ${ }^{44}$ the general implication of the decision is that a defendant like Giles can object to testimony on the grounds of a lack of confrontation that is his own fault. The minority was troubled by this, and would have defined the forfeiture exception more widely.

It is not clear what approach the ECtHR would take where the absence of a witness has been caused by a defendant. In Rachdad, the Court noted that the

41 cf Unterprertinger v Austria (1991) 13 EHRR 175 and Asch v Austria (1993) 15 EHRR 597. Occasionally the test is restricted to 'sole', eg Gossa, n 18 above at [55] (cf [63]); Rachdad v France Appln No 71846/01 (2003) at [24].

${ }^{42}$ See $\mathrm{n} 1$ above at [37]: the court 'doubts', but does not rule out, the possibility of counter-balancing. Later, it discusses the government's counter-balancing arguments on their merits: see [41]-[48].

43 n 12 above.

44 ibid, 23. 
applicant had contributed to the difficulty in securing confrontation: he had apparently been abroad (allegedly to avoid arrest) when he had initially been convicted in his absence, and by the time he appealed his convictions, some five years later, only one witness attended court. ${ }^{45}$ However, a breach of article 6 was still found. In Al-Khawaja and Tabery, the Court referred to the Court of Appeal's judgment in Sellick, noting that that case:

was concerned with identified witnesses and the trial judge allowed their statements to be read to the jury because he was satisfied that they were being kept from giving evidence through fear induced by the defendants. That is not the case in either of the present applications and, in the absence of such special circumstances, the Court doubts whether any counterbalancing factors would be sufficient to justify the introduction in evidence of an untested statement which was the sole or decisive basis for the conviction of an applicant. ${ }^{46}$

This implies that forfeiture would be recognised in a strong case. It may be, however, that like the US Supreme Court, Strasbourg would take a restrictive view of the doctrine..$^{47}$

\section{THEORISING CONFRONTATION}

I observed above that neither the ECtHR nor the US Supreme Court has gone very far in developing an explicit theory of confrontation. Nevertheless, there is value in exploring what these courts have said about the confrontation right, before turning to the rather better developed accounts in the literature. At the outset, it is worth noting that there are two main ways in which confrontation and indeed most procedural rights - can be theorised. Confrontation might be seen as a right that is instrumental to fact-finding, because it in some way promotes accurate verdicts. We can refer to such accounts of confrontation as 'epistemic'. Alternatively, confrontation might be thought of as what we might term a non-epistemic right. On this view, there would be value in a confrontation right in a particular case even if it would not promote accuracy, perhaps because insisting on confrontation is a way of respecting the defendant's dignity. In making

\footnotetext{
45 n 41 above. See also Artner v Austria Appln No 13161/87 (1992) for a similar situation; here the ECtHR found no breach of Art 6 , but it does not appear to have put any weight on an argument for forfeiture, instead relying on the fact that the witness statement was corroborated.

46 n 1 above, 37.

47 In Barberà, Messegué and Jabardo v Spain Appln No 10590/83 (1988) at [82], the Court rejected the argument that a failure to object to a decision not to read out certain statements at trial could be taken as waiver of the confrontation right, commenting that 'According to the Court's established case-law, waiver of the exercise of a right guaranteed by the Convention - in so far as it is permissible - must be established in an unequivocal manner.' See also Craxi v Italy Appln No 34896/97 (2003) at [91].
} 
this distinction, I do not want to suggest that these are mutually exclusive ways of thinking about confrontation. No doubt many who value confrontation do so for a mixture of epistemic and non-epistemic reasons. Nevertheless, the distinction is a useful way of analysing arguments about confrontation.

\section{STRASBOURG}

To date, most of the indications are that the ECtHR understands the value of confrontation in purely epistemic terms. The only two explicit statements about the importance of confrontation seem to be that, where it is lacking, a defendant is deprived of 'any opportunity of observing the demeanour of [the] witness when under direct questioning, and thus of testing her reliability', ${ }^{48}$ and that, in the case of an anonymous witness:

the nature and scope of the questions [the defence] could put were considerably restricted. [...] If the defence is unaware of the identity of the person it seeks to question, it may be deprived of the very particulars enabling it to demonstrate that he or she is prejudiced, hostile or unreliable. Testimony or other declarations inculpating an accused may well be designedly untruthful or simply erroneous and the defence will scarcely be able to bring this to light if it lacks the information permitting it to test the author's reliability or cast doubt on his credibility. The dangers inherent in such a situation are obvious. Furthermore, each of the trial courts was precluded by the absence of the said anonymous persons from observing their demeanour under questioning and thus forming its own impression of their reliability. ${ }^{49}$

As we have seen, however, while face to face confrontation at trial is the preferred method of eliciting testimony, ${ }^{50}$ departures from this ideal can be counterbalanced by the defendant's having the ability to put questions to a witness through a judge or lawyer in a pre-trial process. ${ }^{51}$ The emphasis on reliability is reflected in the comment in Gossa that the evidence of an absent witness should be treated with 'extreme care'. 52 Similarly, in Trivedi v United Kingdom the Commission observed that counsel had been able to comment on the statements of an absent witness 'with a view to casting doubt on his credibility and reliability' and that the jury had been warned to put less weight on the evidence than that of witnesses who had been heard at trial. ${ }^{53}$ In cases where confrontation has been lacking, the

\footnotetext{
$48 P S \mathrm{v}$ Germany, n 18 above at [26].

${ }^{49}$ Kostovski, n 18 above at [42]-[43].

${ }^{50}$ See, eg, Luca, $\mathrm{n} 18$ above at [39].

51 See, eg, $S N$, n 18 above.

52 n 18 above at [55]. See also Doorson, n 7 above, 76; Melnikov, n 36 above, 75 (statements of co-accused require particular care).

53 [1997] EHRLR 521.
} 
emphasis on whether the statement is the sole or decisive evidence also indicates that the unreliability of unconfronted evidence is the key concern.

The only element of the Strasbourg case law that might be hard to square with an emphasis on reliability is the apparent restriction of the confrontation right to some sort of testimonial evidence - statements made to the authorities, or perhaps a narrower group of 'accusatorial' statements. To the common lawyer familiar with the concept of hearsay, this focus might seem odd. The 'hearsay dangers' of veracity, perceptual ability, memory and ambiguity can affect any hearsay evidence and can be best explored through cross-examination of the declarant. Under a non-epistemic conception of the confrontation right, however, it might be thought that the defendant's ability to challenge his accusers - those who denounce him to the authorities - is a way of respecting his dignity. The restriction to statements to the authorities, however, does not necessarily indicate that the ECtHR conceptualises confrontation as a non-epistemic right. A rule that all testimony should be subject to direct challenge by the defendant risks being so broad as to be unworkable, as it would extend to things such as business records. A focus on accusatorial statements to the authorities might then be a way of marking out a particular category of statement that will be potentially outcomedeterminative and where the risks of the witness having an axe to grind (as in the earlier example where the witness to the drive by shooting gives a name to the police) are especially great. Like any rule, this will be imperfect, sometimes being over- and sometimes under-inclusive with regards to its rationale (guaranteeing a reasonable degree of reliability), but it might still draw the line in a sensible place. 54 A problem with this 'rule-utilitarian' defence of the confrontation right, however, is that it fits poorly with the ECtHR's general approach to Article 6. The Court has repeatedly said that it does not lay down specific admissibility rules but makes an overall assessment of whether a trial has been fair; member states therefore have considerable discretion about the way in which a fair trial is delivered. ${ }^{55}$ If, as the English courts claimed in Horncastle, evidence subject to the confrontation right can nevertheless be reliable enough to be properly decisive, then the ECtHR should not use rule-based reasoning to justify an exceptionless right. ${ }^{56}$

\section{CRAWFORD}

When it comes to the US Supreme Court, the first point to make is that, in its recent case law, the Court has taken a relatively originalist approach to interpretation of the Confrontation Clause. Its concern has largely been with how

\footnotetext{
54 It is important to emphasise that just because a statement does not fall within the domain of an absolute inadmissibility rule does not mean that it will be admitted. There might be other reasons for exclusion; in England the issue would fall to be decided under the general rules for the exclusion of hearsay.

55 As Maffei, n 21 above, 71, puts it: 'ECHR rulings on criminal evidence may be seen as a list of "obligations of result", with national courts being allowed to follow their own rules so long as the end result ensures fairness to the defendant.'

56 See further Dennis, $\mathrm{n} 4$ above.
} 
the clause would have been understood at the time of the founding. Thus in Giles the majority's analysis of forfeiture was based almost entirely on the eighteenth century case law. ${ }^{57}$ In this way, the Court has felt little need to justify the confrontation requirement: as noted earlier, it has tended to the view that the 'purpose of confrontation is confrontation'. ${ }^{58}$ Where it has gone further, and discussed the rationale for the right, it has tended to deny that the scope of the right should be moulded by reliability criteria. This is not surprising, because Cranford and its progeny have been trying to distance the Court from the previous Roberts approach, ${ }^{59}$ where a reliability assessment governed admissibility. The most striking rejection of a reliability analysis comes in a footnote in Melendez-Diar:

The analysts who swore the affidavits provided testimony against MelendezDiaz, and they are therefore subject to confrontation; we would reach the same conclusion if all analysts always possessed the scientific acumen of Mme Curie and the veracity of Mother Theresa. ${ }^{60}$

And in Cranford itself: 'Dispensing with confrontation because testimony is obviously reliable is akin to dispensing with jury trial because a defendant is obviously guilty.' 61

However, that reliability is rejected as a touchstone for delimiting the confrontation right does not mean that the right is not justified on reliability grounds. In fact Cranford is explicit that it is:

To be sure, the Clause's ultimate goal is to ensure reliability of evidence, but it is a procedural rather than a substantive guarantee. It commands, not that evidence be reliable, but that reliability be assessed in a particular manner: by testing in the crucible of cross-examination. ${ }^{62}$

Part of the Court's worry here, one reflected in the jury analogy, is probably that judges should not be trusted to make reliability determinations. Thus Roberts is criticised for allowing the jury to hear unconfronted evidence 'based on a mere judicial determination of reliability', ${ }^{63}$ and the Constitution is held to operate as a constraint on judicial discretion. 64 In this way the connection between confrontation and reliability reflects the rule-utilitarian interpretation of the ECtHR's approach explored above. We cannot trust case-by-case judgments of

\footnotetext{
${ }^{57} \mathrm{n} 12$ above.

${ }^{58}$ See $n 8$ above.

${ }^{59}$ See $\mathrm{n} 6$ above.

${ }^{60} \mathrm{n} 14$ above, 14

${ }^{61}$ n 5 above, 62 .

62 ibid, 61.

${ }^{6} 3 \mathrm{ibid}, 62$. The distrust of judges also surfaces in Giles, as a reason for having a narrow forfeiture doctrine. See $\mathrm{n} 12$ above, 11

64 ibid, 67-68.
} 
reliability, so we establish a strict rule even at the price of excluding some reliable evidence. But the Court's approach is not quite this straightforward. Because it has been much more explicit than has the ECtHR in restricting confrontation to testimonial statements, it has had to go some way towards defining 'testimonial'. As the comments about Marie Curie in Melendez-Diaz show, it has not used reliability as a touchstone here, even though that might have been one way of getting a crisp rule ('laboratory reports are not subject to confrontation'). Rather than using reliability to define 'testimonial', the majority on the Supreme Court have preferred to quote from 1828 dictionaries. ${ }^{65}$ One interpretation of what is going on is that there is a mixture of originalism and rule-utilitarianism, where the Court accepts the rule utilitarian balance of the founders. But things are still more complex than this, because in deciding whether confrontation attaches to forms of evidence - 911 calls and forensic scientists' reports - not envisaged in 1791, the Court has had to be somewhat creative. As the majority put it in Melendez-Diaz, ' $[\mathrm{r}$ ] estricting the Confrontation Clause to the precise forms against which it was originally directed is a recipe for its extinction. ${ }^{66}$ To the extent they have been creative, the majority have been criticised for an analysis 'disconnected from the prosecutorial abuses targeted by the Confrontation Clause. ${ }^{\prime} 7$

Another way of interpreting what the Supreme Court has been doing in Cranford and later cases points to a more explicitly non-epistemic basis for its holdings. In the analogy with the right to jury trial, quoted above, there may be an element of 'that's just the way we do things'. We try cases by jury, and we demand that testimony be given in a manner that allows confrontation. This is the way that one important commentator, Richard Friedman, has tended to frame the confrontation right, and Friedman has obviously influenced the Supreme Court. ${ }^{68}$ If we see the confrontation right as historically embedded - as, like jury trial and the adversarial system, part of our culture - then it does not necessarily make sense to ask why we do things that way. ${ }^{69}$

No doubt more could be said about the approach to confrontation taken by the US Supreme Court in its recent decisions; these cases are rich material for exegesis. But given that our focus is ultimately on the situation in Europe, enough

65 ibid, 4.

${ }^{66} \mathrm{n} 14$ above, $16, \mathrm{n} 5$.

${ }^{67}$ Davis, $\mathrm{n} 15$ above, 839-840.

${ }^{68} \mathrm{See}$, eg, R.D. Friedman, “Face to Face”: Rediscovering the Right to Confront Prosecution Witnesses' (2004) $8 E \& P$ 1, 17: 'even if confrontation served no other value at all, it would be important to honour the right that accused persons have had for many centuries governing how witnesses against them may testify'; R.D. Friedman, 'Confrontation: The Search for Basic Principles' (1998) 86 Georgetown LJ 1011 (hereinafter 'Basic Principles'), esp 1028: 'Giving the accused the right to confront the witnesses against him is a fundamental part of the way we do judicial business [...] We should adhere to it even if in the particular case it does not help accurate fact-finding - just as we adhere to the rights of counsel and trial by jury without having to ask whether to do so in the particular case will do more good than harm.' The influence on the Supreme Court can be seen by comparing the 'Basic Principles' essay, especially the jury trial analogy, with the judgment in Cranford.

${ }^{69}$ On this justification for the adversary system, see D. Luban, Lanyers and Justice: An Ethical Study (Princeton: Princeton UP, 1988) 87-92. Luban is sceptical of the argument. 
has been said to give some idea of how the confrontation right currently found in the United States might be justified.

\section{POLICE TACTICS}

When we move beyond the pronouncements of the courts, we find a slightly richer set of theories of confrontation, with more explicit argument about its value. William O'Brian's close analysis of confrontation provides a good starting point. O'Brian argues that the English courts, and the ECtHR, should adopt the rigid approach to confrontation found in Crawford. ${ }^{70}$ For O'Brian, a strong confrontation right 'reflects the fact that "there is something deep in human nature that regards face to face confrontation between accused and accuser as 'essential to a fair trial in a criminal prosecution."'

Although confrontation is clearly of great value in the search for truth [...] it reflects other values as well. Requiring accusers to do so in public and subject to questioning forces them to face the fact that their accusations impose real human costs on their target. It is part of the 'bargain' that we make with the liberal state that, before it can deprive us of our liberty, it must give us a fair hearing at which [...] those who accuse us must have the courage to make their accusations where we can challenge them directly. It also reinforces the right to a jury trial by insisting that the jury, not the judge, make the critical decision on the reliability of evidence..$^{72}$

There is a lot in these remarks. We will explore the idea of something 'deep in human nature' and the demand that accusers be courageous below. As for the rest of the passage, one reason for quoting these comments is that they demonstrate something one commonly finds in discussions of confrontation: that appeals to non-epistemic values of confrontation are often rather nebulous. For one obvious explanation of why it is valuable to have accusers see the human costs of their testimony is that this may make them think twice about lying; our ability to challenge them may also help to expose lies or mistakes. These are obviously epistemic concerns. The right to a jury trial, however, may be a non-epistemic value, but it is not a convincing one in this respect. After all, many trials, even in England, take place without a jury, and even if we confine our focus to jury trials it is not true that juries do not get to decide on the reliability of hearsay.

O'Brian goes on to make a more explicitly epistemic case for confrontation, and here his arguments are more convincing. '[S]tatements that are created once

\footnotetext{
70 O’Brian, n 22 above, 481.

71 ibid, 499. O'Brian is here quoting from Coy v Iowa 487 US 1012 (1988), 1017, which in turn quotes Pointer v Texas 380 US 400 (1965), 404.

72 ibid, 500 .
} 
litigation is anticipated or underway', he notes, 'are inherently suspect. ${ }^{9} 3$ Even where a witness has no axe to grind - recall the Court of Appeal's number plate example - police questioning can be suggestive and manipulative. Margaret Berger has made a similar argument. ${ }^{74}$ While O'Brian's contention seems to be that testimonial hearsay is simply unreliable, Berger puts a slightly different spin on police manipulation. Labelling her account a 'prosecutorial restraint' model, she suggests that because confrontation allows the defence to pose questions about how statements were elicited, it will deter the police from using problematic tactics. She casts this account as non-epistemic, but because the ultimate concern is the quality of evidence that comes before the jury it is better seen, in my terminology, as an epistemic theory of confrontation. ${ }^{75}$

There is certainly good reason to be concerned about police interviews with witnesses. Research in England and Wales found that 'interviews were [...] highly interviewer driven, with a confirmatory bias'. ${ }^{76}$ One assessment concludes that 'Officers are apt to interview witnesses in ways that are wholly improper and ineffective'. ${ }^{77}$ However, a strong confrontation right may not be the best way to deal with the problem. To the extent that the problem is suggestion, where the police version of events is to some degree internalised, cross-examination may be ineffective, especially as trials tend to take place some time after the alleged crime, with witnesses 'refreshing' memory from the witness statement. Berger's hope is that confrontation will encourage better police performance, but, even if crossexamination is good at rooting out police malpractice, there must be some doubt as to whether its prospect will have much impact on the police, especially given the high rate of guilty pleas. ${ }^{78}$ Tape-recording of interviews with witnesses may be a rather more effective way of controlling police tactics, and would allow some assessment of what went on irrespective of whether the witness is available for cross-examination. ${ }^{79}$ By focussing on concerns about presenting the fact-finder

\footnotetext{
73 ibid, 500-501.

${ }^{74}$ M.A. Berger, 'The Deconstitutionalization of the Confrontation Clause: A Proposal for a Prosecutorial Restraint Model' (1992) 76 Minnesota L Rev 557.

75 However, Berger does go somewhat beyond this, noting that because confrontation can bring problematic police tactics to light, it may sometimes prompt the jury to exercise jury equity. ibid, 600 .

${ }^{76}$ C. Clarke and R. Milne National Evaluation of the PEACE Investigative Interviewing Course (London: Home Office, 2001) 58-59.

77 E. Shepherd and R. Milne, "'Have you Told Management about this?" Bringing Witness Interviewing Into the Twenty-First Century' in A. Heaton-Armstrong, et al (eds), Witness Testimony: Psychological, Investigative and Evidential Perspectives (Oxford: OUP, 2006) 58-59.

78 There are parallels here with the debates about deterrence of police misconduct as a rationale for the exclusion of improperly obtained evidence. The literature is massive, but a good sceptical account is C. Slobogin, 'Why Liberals Should Chuck the Exclusionary Rule' (1999) Illinois L Rev 363. My own view is that the sceptical arguments are a bit overdone in the context of the exclusionary rule, but I suspect we have less reason to believe in deterrence where confrontation is concerned: for one thing, we are relying on the ability of cross-examination to bring out manipulation of the declarant, and it must be doubtful whether it often will do.

79 The ECtHR has used tape-recording of witness interviews as one factor in its assessment of whether the confrontation right has been breached: Melnikov, n 36 above at [76]. Of course, tape-recording is not a perfect solution, as conversations may be rehearsed before the tape is switched on. But it is through listening to recordings that the researchers quoted above concluded that police were pursuing a one-sided agenda.
} 
with unreliable evidence, O'Brian escapes these particular criticisms. It is, however, not obvious that the product of police questioning is so unreliable that we are better off not admitting it at all unless there is confrontation - especially if a tape-recording of the interview is available. I return to this point below.

By drawing attention to the possibility of police abuse of the questioning process, O'Brian and Berger gesture at a slightly different value inherent in confrontation. The trial of Sir Walter Raleigh is often taken to be paradigmatic of the possibility of abuse in a system without confrontation. Raleigh was convicted of treason, largely on the basis of the testimony of Sir Thomas Cobham, who had apparently told his questioners that Raleigh had been part of a plot to overthrow James I. ${ }^{80}$ Cobham did not testify at the trial, and, despite Raleigh's pleas and Cobham's availability, the court refused to order that he be brought before it to repeat his accusation. While Raleigh is the best known example, those involved in drafting the US Constitution would have been aware of a long history of similar abuses, including the use of 'ex parte' procedures by the British to try colonists. ${ }^{81}$ In the passage quoted above, O'Brian refers to a bargain with the liberal state. This is unhelpful rhetoric, but we should note that one strand of liberalism is a 'liberalism of fear' 82 where we construct institutions in order to protect ourselves from a state that cannot always be trusted. ${ }^{83}$ With authoritarian government being part of recent European history, we can appreciate that a liberalism of fear may be one reason why the ECtHR has taken to upholding a strong confrontation right and also why English judges, coming from a country with a more stable political history, might react with bemusement. It is well worth highlighting this aspect of confrontation, but the argument is basically an epistemic one, raising issues about the reliability of unconfronted evidence. ${ }^{84}$

\section{IGNOBILITY}

As we have seen, O'Brian refers to the value of having witnesses face those whom they accuse. Above, it was suggested that this was most naturally interpreted as an epistemic justification for confrontation. But in an interesting take on the confrontation right, endorsed by O'Brian, Sherman Clark has developed another way in which we might understand this aspect of confrontation. ${ }^{85}$ Clark labels his

\footnotetext{
${ }^{80}$ Raleigh's Case 2 How St Tr 1.

${ }^{81}$ See Crawford, n 5 above, 47-48.

82 See J. Waldron, 'Security and Liberty: The Image of Balance' (2003) 11 J Political Philosophy 191, 205. Waldron attributes the idea to Judith Shklar: 'The Liberalism of Fear' in N.L. Rosenblum (ed), Liberalism and the Moral Life (Cambridge, MA: Harvard UP, 1989).

${ }^{83}$ This perspective may also help to illuminate the reference to jury trial in Cranford, quoted above at $\mathrm{n} 61$, because the jury is often thought of as an institution that protects defendants from abuse of state power.

${ }^{84} \mathrm{It}$ is also possible to argue that the political context makes modern trials very different from the ones that concerned the framers, and thus that we should give less weight to confrontation than they did. See R.J. Allen, 'From the Enlightenment to Crawford to Holmes' (2009) 39 Seton Hall L Rev 1.

85 S.J. Clark, 'An Accuser-Obligation Approach to the Confrontation Clause' (2003) 81 Nebraska L Rev 1258.
} 
theory an 'accuser obligation' account, whereby confrontation is not so much a duty placed on the state for the defendant's benefit, as a duty placed on citizens to testify in an appropriate manner:

We demand that those who would perform this potentially dangerous, morally weighty, and symbolically loaded act--the act of accusation--be willing to do so face to face. We impose this requirement not only because out-ofcourt accusations are unreliable, though they may often be, but also in response to a deep, if inchoate, feeling that it is somehow beneath us-inconsistent with our sense of who we want to be as a community--to allow witnesses against criminal defendants to "hide behind the shadow" when making an accusation. On this interpretation, requiring confrontation is a way of reminding ourselves that we are, or at least want to see ourselves as, the kind of people who decline to countenance or abet what we see as the cowardly and ignoble practice of hidden accusation. ${ }^{86}$

The central idea is that in some circumstances a witness may behave 'ignobly' by making an accusation and then avoiding confrontation. One significant point about Clark's account, however, is that it probably would not justify excluding the statement to the police in Al-Khawaja. Clark allows that a declarant's inability to testify does not necessarily display the sort of ignobility that the clause guards against, thus in Al-Khawaja the complainant's death makes a good case for admissibility. This underlines the point that confrontation theory matters. Contrast O'Brian's approach, where a statement to the police is the paradigmatic example of evidence that should be excluded. For him, an inability to testify cannot justify admissibility. Another case where the approaches might come apart would be where a declarant is questioned by an undercover police officer posing as a fellow criminal. Here, the declarant would presumably not be aware of the testimonial nature of the statement - she would not expect it to be used in court - and so for Clark the confrontation right would not attach. ${ }^{87}$ But for O’Brian, police manipulation is presumably in issue, so under his primary grounding of the right confrontation would be necessary.

Clark argues that his account can justify a focus on testimonial statements. The more accusatorial a statement, the more problematic we might think it if the declarant avoids confrontation. Clark gives an example of a courier who keeps records of the parcels she delivers. ${ }^{88} \mathrm{He}$ argues that, should the question of whether the courier delivered a particular package to D become an important part of the prosecution's case, there is no right to confront the witness. I do not want

86 ibid, 1258.

87 This would also be the result under Friedman's approach, which emphasises whether the declarant could have been expected to realise that she was making a statement for forensic purposes. See R.D. Friedman, 'Grappling with the Meaning of "Testimonial" (2005) 71 Brooklyn L Rev 241. For the US Supreme Court, the emphasis on the questioner's perspective found in Davis, n 15 above, might lead to a different result.

88 ibid, 1273. 
to press the point, but there may be some question about this: once the courier becomes aware that the defendant's fate hinges on the accuracy of her record, might it not be ignoble of her to avoid the trial? Perhaps this is not as bad as making an accusation never intending to repeat it in the accused's presence. But Clark's account is not confined to such 'hidden accusations', for it includes witnesses who make testimonial statements and later decide not to testify at trial, ${ }^{89}$ a situation which is roughly on a par with the courier example.

\section{SOMETHING DEEP IN HUMAN NATURE}

Clark's analysis of confrontation suggests one way of developing a non-epistemic theory, and removing the focus from reliability. There are other possibilities. Some years before Cranford, the US Supreme Court in Coy v Iowa considered the importance of face to face confrontation in a case involving testimony given by video-link. ${ }^{90}$ The majority quoted from various non-legal sources in order to illustrate the long history of confrontation. It explained that:

This opinion is embellished with references to and quotations from antiquity in part to convey that there is something deep in human nature that regards face-to-face confrontation between accused and accuser as 'essential to a fair trial in a criminal prosecution'. Pointer v. Texas, 380 U. S. 400, 380 U. S. 404 (1965). What was true of old is no less true in modern times. President Eisenhower once described face-to-face confrontation as part of the code of his home town of Abilene, Kansas. In Abilene, he said, it was necessary to ' $[\mathrm{m}]$ eet anyone face to face with whom you disagree. You could not sneak up on him from behind, or do any damage to him, without suffering the penalty of an outraged citizenry [...] In this country, if someone dislikes you, or accuses you, he must come up in front. He cannot hide behind the shadow.' $[\ldots]$ The phrase still persists, 'Look me in the eye and say that.'91

However, the Coy majority ultimately seems to have favoured an epistemic interpretation of the historical importance of confrontation. Thus 'the perception that confrontation is essential to fairness has persisted over the centuries because there is much truth to $\mathrm{it}^{92}$ - the point being the now familiar one that confrontation may aid lie detection. Face to face confrontation was also said to

\footnotetext{
89 Another question is whether Clark can justify a confrontation right in a case where the declarant decides not to testify, not because she lacks the courage to confront $\mathrm{D}$, but because she no longer supports the prosecution: as in a domestic violence case where the declarant becomes reconciled with her partner.

90 n 71 above.

91 ibid, 1017-1018.

92 ibid, 1019.
} 
have 'much the same purpose' as the right to cross-examine: ensuring the integrity of the fact-finding process. ${ }^{93}$

Of course, the 'something deep in human nature' can also be given a nonepistemic interpretation, and some commentators have tried to unpack the idea in this way. For example, Toni Massaro argues that there is more to confrontation than the enhancement of fact-finding. ${ }^{94}$ Linking her analysis to the 'dignitarian' strand in due process theorising, the high point of her argument is that:

Commonly-held notions about 'fair play' and 'decent treatment' of others in social and business relationships indicate that most people accord intrinsic value to face-to-face encounters. [...] The United States military acknowledges this intrinsic value of face-to-face encounters by its practice of delivering the news of the death of a serviceman or woman in person. Likewise, in the business world it is 'indecent' to terminate an employee with a letter, instead of in a face-to-face exchange. To use a letter demonstrates a lack of respect for the affected person, and implies he or she is of low status. People in our culture thus regard the delivery of significant bad news through a letter, a telephone call, or other impersonal devices as the choice of a messenger who is cowardly, or who lacks respect for the equality, humanity, and dignity of the recipient. ${ }^{5}$

The extent to which this analogy works is questionable. If the state introduces the evidence of an absent witness, is it really violating the accused's dignity by treating him in an impersonal manner? The trial itself remains a face to face proceeding, and the accused will hear any bad news - a guilty verdict - delivered personally. At its strongest, Massaro's argument seems to collapse into Clark's: the accuser has an obligation to face the accused.

Eileen Scallen has also tried to tease out reasons why confrontation may be valued apart from its contribution to fact-finding. ${ }^{96}$ She argues that confrontation is necessary 'as part of the social relationship between the individual defendant and the accusing witness', ${ }^{97}$ and draws on social science research on the reasons why people confront each other in everyday life. Many of these reasons do not map easily onto the criminal trial; the strongest point seems to be that confrontation has cathartic functions..$^{98}$ In everyday life confrontation may allow us to vent our frustrations; in a criminal trial perhaps it is important that the defendant should have the satisfaction of seeing his accuser repeat the accusation to his face, even if the witness is an impressive one and her presence actually damages his case.

\footnotetext{
93 ibid.

${ }_{94}^{4}$ T.M. Massaro, 'The Dignity Value of Face-to-Face Confrontations' (1988) 40 U Florida L Rev 863.

95 ibid, 904.

96 E.A. Scallen, 'Constitutional Dimensions of Hearsay Reform: Toward a Three-Dimensional Confrontation Clause' (1992) 76 Minnesota L Rev 623.

97 ibid, 642

98 ibid, 646.
} 
There may be a danger in trying to over-rationalise confrontation. There are other aspects of criminal procedure which we generally take to be important but which are hard to theorise satisfactorily: the privilege against self-incrimination, the exclusion of improperly obtained evidence, and the public nature of the trial are examples.99 Perhaps 'something deep in human nature', or the idea of catharsis, vague though they are, are the best explanations of the non-epistemic value of confrontation that we can expect. Even granting that, though, we should still question whether the importance of confrontation, whatever it may be, can justify a strong confrontation right. Tellingly, neither Massaro nor Scallen argue for a right as strong as the one now supported by the US Supreme Court and the ECtHR, which excludes a witness statement even when its maker has suddenly died. There is, though, the argument favoured by Friedman, which puts a slightly different twist on the idea of 'something deep in human nature'. Confrontation is just the way we do things: testimony must be given in court, and we should not tolerate a system that allows it to be given otherwise. 100 This way of seeing things may make more sense in the US, where the right was written into the Constitution $^{101}$ - though it must be said that Friedman advocates strong confrontation rights in Europe, too. ${ }^{102}$ It is certainly worth contrasting Friedman's position with that of the Canadian Supreme Court, which takes the history to indicate that 'the optimal way of testing evidence adopted by our adversarial system is to have the declarant state the evidence in court, under oath, and under the scrutiny of contemporaneous cross-examination. ${ }^{103}$ The emphasis here is on 'optimal': exceptions are permitted. Even if we read the history as establishing an unbending rule, that does not mean that the right is so valuable that we should not now contemplate exceptions. To return to the jury trial analogy: jury trial has ancient roots, but in England we have recently introduced an exception in cases where there are concerns about the intimidation of jurors. ${ }^{104}$ It is hard to see why history should rule out such a reappraisal of the right.

\footnotetext{
${ }^{99}$ For discussion of these various examples, see A. Duff, et al, The Trial on Trial: Volume 3. Towards a Normative Theory of the Criminal Trial (Oxford: Hart Publishing, 2007).

${ }^{100}$ See $\mathrm{n} 68$ above. Note that this way of putting the argument depends on classifying what the declarant does during police questioning as 'testifying'; this might be disputed.

101 Though this begs various questions about what the founders intended. See, eg, D. Sklansky, 'Hearsay's Last Hurrah' 2010 Sup Ct L Rev (forthcoming).

102 Friedman, n 32 above; R.D. Friedman, 'The Confrontation Right Across the Systemic Divide' in J. Jackson, M. Langer and P. Tillers (eds), Crime, Procedure and Evidence in a Comparative and International Context: Essays in Honour of Mirjan Damaška (Oxford: Hart Publishing, 2008).

$103 \mathrm{R} v$ Khelawon [2006] 2 SCR 787 at [63].

${ }^{104}$ Criminal Justice Act 2003, s 44. See R v Twomey [2009] 2 Cr App R 25.
} 


\section{THE PROBLEM WITH A STRONG CONFRONTATION RIGHT}

This survey of confrontation theory suggests that confrontation is valuable. That is not surprising. But, as should now be obvious, the important question is whether the values underlying the confrontation right justify a right which has roughly the shape and rigidity of the one we find under the ECHR and the US Constitution. In each jurisdiction the right is a strong one, with no exception made for cases such as Al-Khawaja where the declarant is simply unable to testify. But, tellingly, the right is not too strong: it is, after all, subject to forfeiture. Forfeiture seems to me to be a very significant exception to the right, because it is a useful way of testing the coherence of confrontation theory. Any advocate of a really strong confrontation right, which could not be forfeited, would have to accept that a defendant who deliberately killed the key prosecution witness in order to prevent her from testifying might be acquitted as a result, even though the prosecution possessed a detailed and convincing statement from the witness incriminating the defendant. Unsurprisingly, no supporters of confrontation have argued for that result. Yet it may be that the structure of their theories commits them to it. For if the right is otherwise a strong one - no exception for Al-Khawaja - and is an epistemic right, ie it is reliability based, it looks to be very hard to justify a forfeiture exception. Does the defendant who kills the witness forfeit his right to be convicted only on reliable evidence? Consider an analogous situation, where a defendant burns down the forensic science laboratory where important evidence in his case is waiting to be tested. That might stymie the prosecution in its efforts to prove the case against him, but we would surely be reluctant to say that the defendant had forfeited his right to proof beyond reasonable doubt and that we should be satisfied with a lower standard of proof.

Might non-epistemic accounts of confrontation be better able to account for the shape of the right? One difficulty here is that truly non-epistemic theories are elusive. Apparently non-epistemic accounts often seem to resolve themselves into epistemic ones. But if we do allow that there is non-epistemic value in confrontation, it is doubtful that this can justify a strong confrontation right. The most promising non-epistemic account may be Clark's accuser obligation theory. Even if we accept, for the sake of argument, that the ignobility of failing to testify in court can ground a strong confrontation right, the right will be shaped by the presence of ignobility, and will not justify excluding the evidence in Al-Khawaja. Other non-epistemic theories might give some basis for a confrontation right in Al-Khawaja, but they simply look to be too weak to do the work required of them: is Al-Khawaja's inability to attain catharsis really a reason to acquit him? As for the argument from historical embedding - that confrontation, like jury trial, is just the way we do things - it too is destabilised by forfeiture. 105 And if proponents of

\footnotetext{
105 This is most obvious in the US context, where the analogy with jury trial drawn in Crawford simply fails to acknowledge that the right to trial by jury cannot be forfeited. In Giles, n 12 above, 21, the majority acknowledges this point, but uses it against the minority's argument for a wide forfeiture exception, rather than to interrogate the coherence of its own position. Things are different in England, because
} 
confrontation concede that forfeiture is simply a sensible exception to the right, then why should there not be other exceptions?

By distinguishing between different confrontation theories, and dealing with each in isolation, it might be claimed that I am failing to do justice to what is surely the most plausible account of confrontation: that it incorporates all of the different values which have been identified. ${ }^{106}$ But amalgamation makes little difference to the key issues. Exclusion in a case like Al-Khawaja cannot be justified by the accuser obligation elements of the account, so here the focus must be on reliability. But if reliability plays a role in all cases, then forfeiture cannot be justified. Of course, if a witness has been threatened, or killed, there may be no ignobility in her failing to testify; but if the absence of accuser obligation cannot justify admissibility in Al-Khawaja, it cannot justify it in a forfeiture case either.

The arguments so far have been brief, and have not addressed all possible justifications for the sort of confrontation right we find in the United States and Europe. For now, though, I hope to have at least raised serious questions about the case for such a right. Accepting that the doctrinal right has been destabilised, however, does not tell us what the solution should be. If epistemic theories cannot justify forfeiture, does this mean that we should abandon the forfeiture exception? Or should we adopt an accuser obligation approach, and recognise an exception in any case where the declarant is unable to testify? The latter approach seems to me to be on the right track, so far as the shape of the confrontation right is concerned. However, Clark's analysis provides an insufficiently convincing justification for a confrontation right. The better way to think about the value of confrontation is closer to a reliability-based analysis - but reliability is not really the right concept to use.

\section{RELIABILITY AND THE EXCLUSION OF EVIDENCE}

Astute commentators on confrontation have recognised that reliability is a problematic concept in evidence law. ${ }^{107}$ If we took an admonition to exclude unreliable evidence seriously, we might end up excluding all evidence. Eyewitness evidence is an obvious example, but so is confession evidence. Even DNA evidence might be based on a contaminated sample, or be given too much weight by the fact-finder. Moreover, in the context of confrontation, an emphasis on

there is no right to jury trial where there are concerns about jury tampering (see n 104 above). However, there is no need to prove that D is responsible for attempts to interfere with jurors before the right is lost, so rather than an example of forfeiture, this might be better seen as an example of jury trial simply being impractical.

106 This approach is taken by O'Brian, n 22 above, and Friedman, eg, 'Face to Face' n 68 above.

107 See Friedman, 'Basic Principles', n 68 above; D.A. Nance, 'Rethinking Confrontation After Crawford' (2004) 2 International Commentary on Evidence; P. Westen, 'Confrontation and Compulsory Process: A Unified Theory of Evidence for Criminal Cases’ (1978) 91 Harvard L Rev 567. 
reliability is potentially very unruly. It cannot easily justify the focus on testimonial statements (business records can be unreliable), nor even on prosecution evidence. Thus when O'Brian notes that statements made in the shadow of litigation are 'inherently suspect', he risks justifying the exclusion of defence hearsay evidence too. But in reality, reliability is not a very realistic concern when it comes to hearsay evidence. Even if much hearsay evidence is suspect, that does not give us any reason to exclude it unless we think that the fact-finder will give it too much weight, and where hearsay is concerned the empirical evidence lends little support to this possibility. ${ }^{108}$

But if reliability is not a useful concept, does that leave us with no objection to make when the prosecution presents the evidence of an absent witness? There appears to be something very problematic about relying on the evidence of an absent witness when the witness could actually be called to testify. But this is most convincingly explained, not in terms of the prosecution introducing unreliable evidence, but in terms of there being better evidence available: the declarant's testimony in court. This reflects a principle of evidence law sometimes referred to as the 'best evidence principle', which has some claim to be a unifying principle of evidence law. ${ }^{109}$ In this specific context, though, the claim is not that testimony in court is necessarily preferable to an out of court statement. The witness may lie in court, or offer confusing credibility cues. A preferable way to put the point is that bringing the witness to court gives us more evidence - the witness's demeanour as well as her answers to questions on examination and cross-examination. This can be set alongside any out-of-court statement to present the most complete picture possible.

There is a connection here with reliability, in that more evidence is generally better than less if we are trying to find the truth, which is why it is desirable to present any available evidence.110 (Additionally, when the prosecution fails to produce easily available evidence, our suspicions will be raised, as in the Raleigh trial.) The desirability of basing a decision on as much evidence as possible may give us a reason to exclude some hearsay evidence. If the declarant is easily available, we might want to exclude the witness statement in order to provide the prosecution with an incentive to produce the better evidence. However, the fact that the amount of evidence we have is connected to the reliability of the decisions we make gives us no reason to exclude the statement of an absent prosecution witness. Defendants do not have a right to have a particular amount of evidence admitted against them: they have no legitimate complaint if certain evidence, that might be helpful to their case, is missing (so long as it is not the prosecution's fault that it is missing - a point to be taken up below). ${ }^{111}$ We would not stop a trial just

108 R. Park, 'Visions of Applying the Scientific Method to the Hearsay Rule' (2003) Michigan State L Rev 1149 .

${ }^{109}$ D.A. Nance, 'The Best Evidence Principle' (1987) 73 Iowa L Rev 227.

110 Alex Stein has denied this: see Foundations of Evidence Law (Oxford: OUP, 2005). For discussion, see M. Redmayne, 'The Structure of Evidence Law' (2006) 26 OJLS 805, esp 814-815.

111 As Nance, n 107 above, 10, puts it: 'It is senseless to disadvantage or penalize the prosecution in the confrontation context, by excluding probative evidence - just because the situation makes it more 
because a key defence witness has dropped dead. ${ }^{112}$ What defendants do have a right to is to proof beyond reasonable doubt. But that is an issue of sufficiency of evidence, about when a case is strong enough to be left to the jury, not a doctrine about what evidence can be admitted. To be sure, concerns about sufficiency of evidence may be germane in prosecutions based on the evidence of an absent witness, but that is a reason for withdrawing some cases from the jury, not for a rigid rule making all testimonial hearsay inadmissible.

At this point, an analogy may be helpful. Courts sometimes face difficult decisions about whether to allow a case to go to the jury when the alleged crime occurred a long time ago. ${ }^{113}$ The passage of time may well mean that there is less evidence available than there would otherwise be. It may, in particular, mean that evidence of potential use to the defence will no longer be available. In the way English courts approach such cases we do find some support for the sort of approach the ECtHR takes to confrontation; but not, I suggest, enough to ground a strong right to confrontation.

In some cases where delay has led to the loss of potentially exculpatory evidence - such as documents, or evidence to support an alibi - courts have stayed proceedings. For example, in $B$ the defendant had been convicted of sexual offences allegedly committed some 30 years earlier. ${ }^{114}$ While not criticising the conduct of the trial, the Court of Appeal held that D's conviction was unsafe: 'All that the defendant could do was to say that he had not committed the acts alleged against him. [...] [W] hen faced with allegations of the sort that were made here, "I have not done it" is virtually no defence at all.'115 Shortly afterwards, the Court expressed some doubt about this decision, but also noted that one distinguishing feature of the appeal currently before it was that there was some material that could be used in cross-examination of the complainant.116 In $A l i$, the Court of Appeal reflected on the issues: 'The mere fact that missing material might have assisted the defence will not necessarily lead to a stay'; there should, however, be 'sufficiently credible evidence, apart from the missing evidence, leaving the defence [sic] to exploit the gaps left by the missing evidence. The rationale for refusing a stay is the existence of credible evidence, itself untainted by what has gone missing. ${ }^{117}$

While the Court of Appeal has not always taken a consistent line in cases where a defendant has been disadvantaged by delay, ${ }^{118}$ it does seem that there is

difficult for the accused to defend himself than it might have been under an hypothesized alternative reality.'

112 See Westen, n 107 above.

113 For detailed discussion, see D. Hamer, 'Trying Delays: A Balanced Response to Forensic Disadvantage', unpublished ms, on file with the author. See also A. Choo, Abuse of Process and Judicial Stays of Criminal Proceedings (Oxford: OUP, 2nd ed, 2008) ch 3.

114 [2003] EWCA Crim 319.

115 ibid at [28].

116 R v E [2004] 2 Cr App R 36.

117 [2007] EWCA Crim 691 at [29]-[30] (original emphasis).

118 See R v S [2006] EWCA Crim 756, which lays down a series of principles to govern delay cases and suggests that, where there is no fault on the part of the prosecution, stays should be exceptional. It is also 
considerable unease about the fairness of a trial in which a defendant is not able to challenge the evidence against him. This chimes quite well with the approach the ECtHR takes to confrontation. As we have seen, the Court does not hold that defendants have a right of face to face confrontation with even accusatorial witnesses; instead, defendants seem to have a right to challenge such witnesses. While the case law usually takes challenge to involve an ability to put questions to a witness, in Al-Khawaja the Court did not quite rule out the possibility that some less direct means of challenge might be acceptable. ${ }^{119}$ The Court engaged with the UK Government's argument that the presence of two 'recent complaint' witnesses at the trial, to whom the complainant had made allegations about D, counterbalanced D's lack of direct confrontation by allowing him to explore inconsistencies between the accounts. The Court, however, was unimpressed by this argument, because the inconsistencies between the accounts were minor. ${ }^{120}$ This is a painfully bad response to the Government's point - it is rather like saying that a defendant had an unfair trial because the evidence pointed overwhelmingly towards guilt. What surely matters, and helps to make the trial fair, is that AlKhawaja had access to evidence that could potentially have undermined the case against him.

What should we make of the analogy with the delay cases? It is possible to take a fairly hard-headed view, and to argue that so long as the prosecution case is strong enough to go to the jury, then the fact that the accused no longer has access to evidence that might have helped his case is neither here nor there. The best way to see the problem in $B$ - and perhaps some of the other cases - then, may be that the case was not strong enough to go to the jury. English courts might be reluctant to put the point this way, because the principle in Galbraith ${ }^{121}$ is that issues of credibility are for the jury, and thus that so long as the complainant makes a coherent allegation, the accused has a case to answer. But that the crime simply cannot be proved beyond reasonable doubt is surely an apt diagnosis when the prosecution case rests on a thirty-year-old allegation with no corroboration. We might say that the problem is that we simply have no way to test the evidence, and that untested evidence is weaker - so long as testing is understood to incorporate not only challenges by the defence, but also whether the evidence fits with any prosecution evidence. In this way, cross-examination is not significant in itself, but only as one of a range of ways of resolving (or not) doubts about the prosecution case. In Al-Khawaja the supporting evidence spoke to some doubts about the complainant, making the case a reasonably strong one to leave to the jury. But Al-Khawaja's sibling case, Tahery, is a different matter. Here the victim was unable to say for certain who his attacker was, and the key prosecution witness,

worth noting that courts are reluctant to take strong action where a defendant has lost an opportunity to challenge eyewitness evidence through an identification procedure: see A. Roberts, 'Pre-Trial Defence Rights and the Fair Use of Eyewitness Identification Procedures' (2008) 71 MLR 331.

119 See n 42 above.

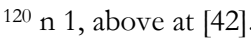

${ }^{121}$ R v Galbraith [1981] 2 All ER 1060. 
who was absent, had made a statement that was in certain respects inconsistent with the victim's evidence.122 This was a weak case, and there is a good argument that it should never have been left to the jury. ${ }^{123}$

If, however, it is thought that there is independent significance in the defendant's ability to challenge the prosecution case, one should note that while the defendant may be more or less defenceless in some of the delay cases, the inability to question a prosecution witness does not always leave a defendant in such a situation. Thus, as we have seen, Al-Khawaja did have potential resources with which to challenge the prosecution case (even Tahery did, in that he could point to inconsistencies between the accounts). It is in fact an important part of the Criminal Justice Act scheme for regulating hearsay evidence that the accused is allowed to introduce evidence relating to the absent witness's credibility including evidence which he might not be able to call were the witness present in court. ${ }^{124}$ Indeed, we should be wary of depicting cross-examination as always being the most effective way of challenging witnesses. Where, for example, expert evidence is concerned, alternative means of challenge, such as disclosure and funding for defence experts, may be more helpful. ${ }^{125}$

\section{RETHINKING CONFRONTATION}

Much of the argument to this point has taken issue with advocates of a strong confrontation right. The argument has also tended to focus on the situation in $\mathrm{Al}$ Khawaja - where a witness has unexpectedly died - to tease out some of the problems with a strong right. More now needs to be said about how the theoretical commitments underlying the argument - largely, the best evidence principle - shape a confrontation right, and what the implications are for less absolute causes of absence.

In the preceding section, it was argued that it may be problematic if the prosecution does not present the best available evidence at trial. This suggests that we can think of the confrontation right as being a right to cross-examine available witnesses. As we have seen, advocates of a strong confrontation right have tended to restrict the scope of the right to a certain class of witnesses: roughly, ones who make accusations. However, having rejected the arguments for a strong right, we

\footnotetext{
122 The case was heard together with Al-Khawaja in the ECtHR: see $\mathrm{n} 1$ above. The facts are clearer in the Court of Appeal's decision: [2006] EWCA Crim 529.

${ }^{123}$ In theory, s 125 of the Criminal Justice Act 2003 provides some protection here. This gives a court the power to direct an acquittal where the prosecution case depends on hearsay evidence which is so unconvincing that a conviction would be unsafe. It is not clear how much of a safeguard this provides in practice. In Joyce [2005] EWCA Crim 1785 at [19], the section is said not to set a higher standard than Galbraith, which is slightly troubling.

${ }^{124}$ Criminal Justice Act 2003, s 124.

${ }^{125}$ See Sklansky, n 101 above.
} 
are left with little reason to restrict the right in this way. The accusatorial designation may provide a rough pointer to the witnesses whom it is most important to cross-examine, but no more than that. To return to Clark's example of a courier who keeps a record of the packages she delivers: should that person's evidence turn out to be crucial to the prosecution's case, we might well want to say that the accused has a right to cross-examine her about the accuracy of the record. But what if the courier has moved abroad, or can no longer remember much about the package in question? The framework for answering these questions is provided by the best evidence principle. 'Best' is obviously a potentially unruly criterion. We could always demand that the prosecution put more resources into a particular investigation and so produce better evidence. To prevent unreasonable demands, best must be understood in terms of what is reasonably practicable, as should availability for the purposes of confrontation. A witness should not be considered to be available if, like the factory workers in Myers, ${ }^{126}$ it is unlikely that she can remember much about the relevant facts. Nor if the witness has moved to Australia and her testimony is not expected to add much of significance.

The confrontation right, then, should be understood as a right to confront witnesses who are practically available. But while the concept of practical availability is intended to block unreasonable demands, it should also sanction unreasonable laziness. Even if, by the time of the trial, better evidence than the witness statement is not available, it might still be appropriate to exclude the statement if we could have expected the prosecution to do better. (Here, the parallel with cases involving delay re-emerges, because questions of prosecution fault are one factor the courts consider in these cases when deciding whether to allow a prosecution to proceed. ${ }^{127}$ ) For example, in Cole a witness was unavailable at trial because of complications surrounding the birth of her child: one might have expected the prosecution to have scheduled the case so as not to fall near the expected birth date. ${ }^{128}$ In Keet two elderly witnesses were too frail to give evidence by the time of trial - one even had dementia. ${ }^{129}$ In this situation a solution might have been to arrange confrontation prior to trial, something accepted under the ECHR and under the Sixth Amendment. Yet, as John Spencer notes, English law simply has no provision that would allow this to occur. ${ }^{130}$ In a broad sense this is the fault of the state. Here, there might be an argument for excluding the evidence in order to provide an incentive to develop better procedures for prosecuting crime. ${ }^{131}$ Similarly, arguments based on a best evidence view of confrontation

\footnotetext{
126 n 11 above.

127 See, generally, A. Ashworth and M. Redmayne, The Criminal Process (Oxford: OUP, 4th ed, 2010) ch 9.4

${ }^{128} \mathrm{R} v \mathrm{v}$ Cole and Keet [2007] 1 WLR 2716.

129 ibid.

${ }^{130}$ Spencer, n 17 above, 57-60; J.R. Spencer, 'Squaring up to Strasbourg: Horncastle in the Supreme Court' (2010) 1 Archbold Review 6.

131 Similar arguments can be used to justify the exclusion of expert evidence where, although better evidence is not immediately available, it is felt that better evidence should be available because insufficient research has been conducted (fingerprint evidence is a possible example). See, generally, M. Redmayne, Expert Evidence and Criminal Justice (Oxford: OUP, 2001) ch 5.
} 
rights might be used to press the state to tape-record witness statements, something which would enhance the ability of defendants to challenge witnesses, whether or not the witness was absent at trial. ${ }^{132}$

Once we open up questions of what is practical, however, and allow that this may include obligations on the state to reform its procedures so as to give better opportunities for confrontation, even the proper response to the Al-Khawaja situation may be debatable. While in this scenario the witness's unavailability at trial is unpredictable, proponents of a strong confrontation right still argue that the statement should be excluded because, among other reasons, 'the prosecution can greatly reduce, if not eliminate, this risk [of unavailability] by affording the defendant an early opportunity to confront the witnesses.' 133 The idea seems to be that in any case the prosecution should insure against the risk of a significant witness becoming absent by arranging pre-trial confrontation. But if confrontation is as valuable as proponents of a strong right make out, this is probably not an effective solution. Just as defendants preferred to keep their powder dry rather than cross-examine witnesses when 'live' committal proceedings were available, ${ }^{134}$ it seems unlikely that many defendants would avail themselves of the opportunity to question a witness long before trial when there was no hint that the witness would not be available at trial. Confrontation would then be a rather hollow right in cases of unpredictable absence. If this is wrong, and significant numbers of defendants were in fact to take up pre-trial confrontation, there would be very considerable resource implications, all as a way of dealing with a problem in a handful of cases. Perhaps there is room here for opinions to differ, but without convincing theoretical arguments for a strong confrontation right it is very difficult to see why the lack of automatic pre-trial confrontation rights should be held against the state.

It will be obvious that the sort of weak confrontation right advocated here gives reasonable scope to judicial discretion in deciding questions of practical availability. And here, as we have seen, proponents of a strong right have one further argument to draw upon. They might concede many of the arguments made here, but still argue for a strong right on rule-utilitarian grounds, because such a right would prevent judges from admitting unconfronted evidence too readily. The rule-utilitarian argument, however, is an argument for clear rules, and not necessarily for the shape of the rules favoured by advocates of a strong confrontation right. To focus once again on the Al-Khawaja situation, where there is obvious inability to testify through no fault of the prosecution: this can still be carved out as a clear exception to a rigidly defined confrontation right. Of course,

132 The ECtHR case law offers some purchase to an argument along these lines. In Gossa, n 8 above at [55], it was observed that Art 6 'requires the contracting states to take positive steps so as to enable the accused to examine or have examined witnesses against him'. On tape recording, see also Melnikov, n 36 above at [76].

133 O’Brian, n 22 above. O’Brian here echoes Friedman, see eg 'Basic Principles', n 68 above, 1035.

134 See Ashworth and Redmayne, n 127 above, ch 9.1. 
once an exception like this is recognised we will need to trust judges to make careful sufficiency decisions in individual cases, and the criticism of Tahery, above, suggests that sometimes this trust may be misplaced. However, if advocates of a strong right are not prepared to allow this much judicial discretion, then they should rule out a forfeiture exception too (because some cases where the accused is deemed to have forfeited his right will nevertheless be too weak to go to the jury), ${ }^{135}$ something that none of them seem prepared to do. Further, if there is a problem with judicial sufficiency determinations, this affects more cases than ones involving absent witnesses. There may well be arguments for reform of the Galbraith rule, but that is a wider issue than can be considered here. ${ }^{136}$

The weak confrontation right advocated here obviously extends judicial discretion beyond Al-Khawaja, to include wider questions of practical availability: should the prosecution, for example, be permitted to rely on the statement of a witness who has moved to Australia? Or what if the witness, as in Tahery, claims to be scared of testifying but there is no suggestion that it is the defendant who has caused the fear? Perhaps there would be a case for a strict rule that witness statements should be inadmissible in such situations were the rule confined to a narrow category of plainly accusatory (as opposed to implicatory) statements. This might pick out a group of witnesses where we would always have reason to think that the best evidence - testimony from a witness subject to cross-examination would have sufficient added value that questions of practical availability should not be considered. ${ }^{137}$ But once a strong confrontation right extends beyond this, to include testimonial witnesses, or all who make statements to the police, then the cost of the right in terms of failed prosecutions means that we need a better argument than simple generalised distrust of judicial discretion. Judicial discretion, after all, can be structured and restrained, as it is under the Criminal Justice Act 2003 and its case law. Without evidence that this scheme is not working, the case for a strong confrontation right remains to be made.

One final point is worth making. As we have seen, part of the historical memory attached to confrontation is fear of state abuse - a 'liberalism of fear', as it was characterised. A weak confrontation right, as developed here, is reasonably well placed to respond to such concerns. ${ }^{138}$ Only if the declarant is unavailable for reasons that the state is not responsible for will there be a strong case for

\footnotetext{
${ }_{135}$ See, eg, $R$ v $M$ [2003] 2 Cr App R 357.

136 The Criminal Cases Review Commission has suggested that judges are too ready to allow cases to go to the jury: Memorandum to Home Affairs Committee, HC 1703 2005-6, para 3.1. The Royal Commission on Criminal Justice argued that judges should stop a case whenever they considered that a conviction would be unsafe: Report (London: HMSO, 1993) 59. See further Ashworth and Redmayne, n 127 above, ch 11.2.

137 There are complex issues about victim's rights here. If the witness is not testifying because of fear, it might be argued that a strong confrontation right conflicts with the victim's right to security of person. While the conflict could be resolved by simply dropping the prosecution, rather than compelling the witness to testify, there is then a difficult question about whether the victim has a sufficiently strong interest in seeing 'their' offender prosecuted that there would still be a conflict of rights. The public interest in seeing offenders convicted is also relevant here.

138 See Nance, n 107 above, who frames his 'best evidence' approach to confrontation as one that guards against government abuse of the criminal process.
} 
admissibility of the witness statement. Of course, this will not be a guarantee against state abuse. One might worry that the state has made a witness disappear, faked her suicide, or bought her a ticket to Australia. In particular, cases where the witness claims to be scared of testifying will raise difficult questions - but so they will even under a strong confrontation right, unless forfeiture is rejected or tightly restricted.

\section{CONCLUSION}

In this paper, I have argued that a strong confrontation right, as found in the United States and under the ECHR, cannot be justified. Epistemic justifications are problematic in themselves, and struggle to account for a forfeiture exception that would keep the right within acceptable limits. Non-epistemic justifications are not sufficiently compelling to support a strong right. Drawing on the best evidence principle, I have argued that confrontation should be seen as a positive right to examine available prosecution witnesses, not as a negative right against having the evidence of absent witnesses admitted.

While the contours of a weak confrontation right have been outlined, I have not descended to the level of detail on questions of admissibility. To a large extent the arguments here justify the status quo under the Criminal Justice Act 2003 and its defence by the English courts in Horncastle. However, I have also raised questions about whether the English criminal justice system is doing what it reasonably can to secure confrontation rights. In this respect, tape-recording of witness interviews and measures to allow pre-trial confrontation in cases where witness unavailability can be foreseen are relatively simple reforms that would do much to enable defendants to challenge the evidence of absent witnesses. 